No 4078

Studia nad Autorytaryzmem i Totalitaryzmem 43, nr 4 Wrocław 2021

https://doi.org/10.19195/2300-7249.43.4.8

\author{
PIOTR KAPUSTA \\ ORCID: 0000-0003-2002-5419 \\ Uniwersytet Zielonogórski \\ p.kapusta@wpa.uz.zgora.pl
}

\title{
Skutki ideologizacji preambuły kodeksu pracy
}

Słowa kluczowe: ideologizacja, indoktrynacja, socjalistyczne stosunki pracy, lud pracujący, zasada jedności praw i obowiązków.

\section{EFFECTS OF THE IDEOLOGIZATION OF THE PREAMBLE TO THE LABOUR CODE}

\begin{abstract}
The post-totalitarian authoritarianism of the Polish People's Republic of 1956-1989 was based on, among others, indoctrination. It was carried out not only through the media and the education system. The law also served this purpose. The adoption of the Labour Code provided the basis for using the educational function of the preamble to shape and consolidate politically desirable patterns of behaviour in socialist labour relations. The content of the Preamble to the Labour Code not only reflected the goals set by the legislator of the adopted legal regulation, but, being saturated with ideological issues, it set the directions for adopting and applying labour law provisions and defined the desired behaviour patterns. Due to the content of individual editorial units, the Preamble to the Labour Code was not only of legal importance, but also some parts of it were normative.
\end{abstract}

Keywords: ideologization, indoctrination, socialist labour relations, working people, the principle of unity of rights and obligations.

\section{Uwagi wstępne}

Wejście w życie z dniem 1 stycznia 1975 roku ustawy z dnia 26 czerwca 1974 roku - Kodeks pracy ${ }^{1}$ zakończyło prace zainicjowane w 1968 roku na V Kongresie Polskiej Zjednoczonej Partii Robotniczej, podczas którego na mocy politycznej decyzji postanowiono powierzyć Centralnej Radzie Związków

\footnotetext{
${ }^{1}$ Dz.U. z 1974 r. Nr 24, poz. 141; dalej: k.p.
} 
Zawodowych przygotowanie kodyfikacji prawa pracy. Zarówno rozpoczęcie prac nad treścią aktu prawnego, jak i ich przebieg były kontrolowane politycznie przy jednoczesnym wyraźnym ograniczeniu akademickiej refleksji nad proponowanymi rozwiązaniami. W efekcie przygotowano i wprowadzono w życie regulacje prawne wieńczące proces kształtowania systemu socjalistycznego prawa pracy w Polsce ${ }^{2}$.

Skutków działalności prawotwórczej nie można rozpatrywać tylko przez pryzmat jej znaczącego wpływu na usamodzielnienie się prawa pracy jako odrębnej gałęzi prawa ${ }^{3}$. Nie można tracić z pola widzenia okoliczności politycznych powstania k.p. ${ }^{4}$ i ich oddziaływania na jego postanowienia. Założenia socjalistycznej myśli prawniczej były widoczne nie tylko w treści poszczególnych artykułów. Wyrażała je już sama preambuła k.p. Wykorzystanie przez ustawodawcę funkcji propagandowej, perswazyjnej i wychowawczej wstępu do ustawy ${ }^{5}$ wpisywało się w prowadzony przez ówczesną władzę proces indoktrynacji. Najczęściej wskazuje się, że jest ona prowadzona z wykorzystaniem środków masowego przekazu i systemu oświaty ${ }^{6}$, jednak nie można wykluczać posługiwania się innymi metodami - również aktem normatywnym.

Choć w teorii prawa znaczenie wstępu do aktu prawnego nie jest jednolicie wyjaśniane, to jednak w przypadku k.p. oddziaływanie preambuły na przepisy prawa pracy $\mathrm{i}$ ich stosowanie nie pozostało niezauważane. Celem niniejszego opracowania jest wskazanie, że preambuła k.p. nie tylko wyrażała wartości preferowane przez władzę polityczną, ale i wskazywała już w pierwszych słowach ustawy pożądane zachowania $\mathrm{w}$ sferze stanowienia i stosowania prawa pracy. Zwrócić należy uwagę na wpływ preambuły k.p. nie tylko na treść norm prawnych prawa pracy, ale również na świadomość obywateli i kulturę prawną.

Zakres i ramy artykułu nie pozwalają na wnikliwą analizę każdego sformułowania preambuły k.p. i jego skutków. W pierwszej kolejności wyjaśnione zostaną w niezbędnym zakresie zagadnienia terminologiczne. Następnie zostaną

2 Zob. M. Seweryński, Refleksje na czterdziestolecie kodyfikacji prawa pracy, [w:] 40 lat Kodeksu pracy, red. Z. Góral, M.A. Mielczarek, Warszawa 2015, s. 22.

3 Zob. W. Szubert, Zagadnienie kodyfikacji prawa pracy, „Państwo i Prawo” 1962, z. 8-9.

${ }^{4} \mathrm{Na}$ marginesie należy zauważyć, że decyzją polityczną wyłączono z prac nad przygotowaniem projektu k.p. przedstawicieli nauki prawa pracy. Jedynym pracownikiem naukowym uczestniczącym w tych działaniach był prof. Wojciech Muszalski - wówczas mający stopień doktora. Pozbawienie kadry naukowej możliwości oddziaływania na kształt i treść przyszłych regulacji spotkało się zresztą z niezadowoleniem świata nauki. $Z$ tego powodu niezwykle interesujące jest streszczenie prac legislacyjnych zawarte w opracowaniu W. Muszalskiego, Tworzenie $i$ wydanie Kodeksu pracy - wspomnienie świadka, [w:] Prawo pracy. Między gospodarka a ochrona pracy. Księga jubileuszowa Profesora Ludwika Florka, red. M. Latos-Miłkowska, Ł. Pisarczyk, Warszawa 2016.

5 Zob. między innymi M.E. Stefaniuk, Preambuła aktu normatywnego $w$ doktrynie oraz w procesie stanowienia i stosowania polskiego prawa w latach 1989-2007, Lublin 2009, s. 58-61.

${ }^{6}$ Według wydanego przez PWN leksykonu pedagogiki indoktrynacja to proces wpajania członkom społeczeństwa przekonań, zwłaszcza politycznych i społecznych, będących w interesie grup rządzących, za pomocą uporczywej propagandy prowadzonej przez środki masowego przekazu czy system oświaty (Indoktrynacja, [hasło w:] Pedagogika, red. B. Milerski, B. Śliwerski, Warszawa 2000, s. 84). 
rozpatrzone - w kontekście powiązanych instytucji prawa pracy stanowiących ich rozwinięcie normatywne - wybrane przykłady ideologicznie nacechowanych wypowiedzi ustawodawcy. Podjęta zostanie także próba pokazania oddziaływania zideologizowanych postanowień ustawy na świadomość prawną obywateli i kulturę prawną. W pracy zastosowanie znajdzie przede wszystkim metoda dogmatycznoprawna, z uwzględnieniem wypowiedzi judykatury. Mając na uwadze uchylenie w 1996 roku preambuly k.p., opracowanie to ma walor historycznoprawny, choć nie brak w nim uwag o charakterze ogólnym.

\section{Preambuła aktu prawnego — pojęcie i funkcja}

Językowe rozumienie terminu ,preambuła” nakazuje przyjąć, że jest to ,uroczysty wstęp poprzedzający właściwy tekst jakiegoś ważnego aktu prawnego, np. konstytucji, wyjaśniający główne motywy i cele tego aktu"7. W nauce prawa akceptuje się przytoczoną definicję analizowanego pojęcia. Wskazuje się przy tym, że ,preambułę można odnaleźć zazwyczaj w aktach o charakterze powszechnie obowiązującym - regulujących jakąś doniosłą społecznie kwestię lub o istotnym znaczeniu politycznym. Do tych zaliczane są przede wszystkim konstytucje, umowy międzynarodowe oraz ustawy regulujące kwestie istotne dla ustroju państwa"8. Z uwagi na jej ustrojowe znaczenie w nauce prawa najczęściej bada się znaczenie treści preambuły konstytucji.

Ponieważ preambuła stanowi część aktu prawnego, sama w sobie również ma charakter prawny. W literaturze nie ma jednak zgody co do tego, czy jej postanowienia mają charakter normatywny. Analizując wypowiedzi formułowane w odniesieniu do ustawy zasadniczej, można odnieść wrażenie, że dominuje tendencja do doszukiwania się normatywnego charakteru jej postanowień. Należy opowiedzieć się za tą grupą poglądów, które przypisują preambule (lub jej części) charakter normatywny w sytuacji, gdy z jej treści można zdekodować normę prawną lub gdy jej postanowienia są co najmniej współstosowane z innymi przepisami ${ }^{9}$. Kiedy jednak preambuła jako część aktu normatywnego nie stanowi

7 Preambuła, [hasło w:] Wielki słownik języka polskiego PWN. O-Q, red. S. Dubisz, Warszawa 2018, s. 913.

8 Zob. B. Sosnowski, Geneza, rola i cechy preambuly w aktach prawnych, „Zeszyt Studencki Kół Naukowych Wydziału Prawa i Administracji UAM" 2016, nr 6, s. 207.

9 Zob. J. Trzciński, Charakter i struktura norm konstytucyjnych, [w:] Projekt Konstytucji RP $w$ świetle badań nauki prawa konstytucyjnego: materiaty konferencji Gdańsk 7-9 marca 1997, red. K. Działocha, A. Pułło, Gdańsk 1998, s. 31; A. Gwiżdż, Wstęp do konstytucji — zagadnienia prawne, [w:] Charakter i struktura norm konstytucji, red. J. Trzciński, Warszawa 1997, s. 183; B. Banaszak, Porównawcze prawo konstytucyjne wspótczesnych państw demokratycznych, Kraków 2004, s. 130; L. Garlicki, Preambuła, [w:] Konstytucja Rzeczypospolitej Polskiej. Komentarz, t. 5, red. L. Garlicki, Warszawa 2007, s. 4; K. Complak, [w:] Konstytucje Rzeczypospolitej oraz komentarz do Konstytucji RP z 1997 roku, red. J. Boć, Wrocław 1998, s. 12-13; J. Wawrzyniak, Zarys polskiego ustroju konstytucyjnego, Bydgoszcz 1999, s. 90. 
źródła wzorca odpowiedniego zachowania obywateli, należy jej przypisywać doniosłość prawną ${ }^{10}$. W ten sposób prawne znaczenie preambuły nie zostaje pominięte, gdyż jej postanowienia muszą być uwzględniane w procesie wykładni i stosowania przepisów danego aktu prawnego, a w przypadku kodeksów również przy tworzeniu regulacji stanowiących element danej gałęzi prawa. Zatem w żadnym wypadku nie można deprecjonować znaczenia wstępu do ustawy ${ }^{11}$.

\section{Charakter preambuły kodeksu pracy}

Nawiązując do wyjaśnień Bogusława Banaszaka dotyczących preambuły Konstytucji Rzeczypospolitej Polskiej z 1997 roku, należy wskazać, że preambuła k.p. dostarcza opartych na autentycznej wypowiedzi ustawodawcy wskazówek co do zgodnych z jego intencjami kierunków interpretacji postanowień tego aktu prawnego. W tym ujęciu są one jednym ze środków kształtujących pożądane z punktu widzenia ustawodawcy postawy jednostek. Ponadto tworzą one również wzorce działalności organów państwowych w tym zakresie ${ }^{12}$.

Odnosząc się bezpośrednio do preambułyk.p., Jan Jończyk wyjaśnia, że ,wstęp niewątpliwie jest integralną częścią ustawy, czy i jaką wartość normatywną mają poszczególne zdania wstępu, zależy od ich treści i przyjętych sposobów interpretacji prawa"13. Choć przy pierwszej lekturze odnieść można wrażenie, że przesiąknięta ideologią treść preambuły do k.p. służy tylko realizacji celów propagandowych, to jednak pod jej ,szatą językową [...] kryją się [...] pewne treści normatywne adresowane do określonych w Kodeksie pracy podmiotów i mówiące o ich powinnościach, zwłaszcza co do sposobu tworzenia, interpretacji i stosowania prawa pracy. Niektóre tezy wstępu są sformułowane wprost w stylu normatywnym (powinnościowym)" "14. Stąd też należy przyjąć, że o ile wiele ze

10 Szerzej zob. A. Choduń, Sens ,,charakteru normatywnego”, „inGremio” 2016, nr 103, https://ingremio.org/2016/11/sens-charakteru-normatywnego/ (dostęp: 30.10.2021).

11 Znaczenie treści preambuły do aktu prawnego wyjaśnia się także w orzecznictwie. Najwyższy Sąd Administracyjny w wyroku z dnia 7 sierpnia 1984 roku (II SA 735/84) wskazał, że „preambuła nie jest normą prawną, stanowi natomiast pochodzące od organu, który wydał akt prawny zaopatrzony w preambułę, wyjaśnienie podstawowych motywów, dla jakich został wydany akt. Motywy te nie mogą pozostawać bez wpływu na wykładnię norm prawnych zawartych w danym akcie. Przy interpretowaniu bowiem treści normy prawnej szczególną rolę odgrywa ustalenie celu normy, to znaczy rezultatu, jaki w sferze stosunków społecznych zamierzono osiągnąć za pomocą danej normy. Ten rodzaj wykładni prawa, zwanej wykładnią celowościową, wymaga uwzględnienia wielu elementów. Jednym z najważniejszych jest właśnie treść preambuły aktu prawnego jako bezpośredniej wypowiedzi na ten temat organu, od którego akt pochodzi”.

12 Zob. B. Banaszak, Konstytucja Rzeczypospolitej Polskiej. Komentarz, Warszawa 2012, s. 5.

13 J. Jończyk, Prawo pracy, Warszawa 1995, s. 63.

14 Ibidem, s. 43. 
sformułowań wywołuje wrażenie „daniny ideologicznej”" postanowień preambuły do k.p. nie można odmówić charakteru normatywnego.

\section{Znaczenie pracy w państwie ludu pracującego}

W pierwszym zdaniu preambuły k.p. wskazuje się, że ,praca w Polskiej Rzeczypospolitej Ludowej, w państwie ludu pracującego jest podstawowym prawem, obowiązkiem i sprawą honoru każdego obywatela". W postanowieniu tym pojawia się odwołanie do kategorii ludu pracującego, które to pojęcie rozumiano jako „wspólnotę ludzi żyjących z pracy w społecznie użytecznej i niewyzyskujących innych, złączonych więzią państwowo-prawną" "16. Użycie tego terminu stanowiło nawiązanie do ustroju socjalistycznego Polskiej Rzeczypospolitej Ludowej. Ugruntowane w społeczeństwie znaczenie tego pojęcia w kontekście preambuły miało zaś, jak można przypuszczać, podkreślić przynależność ludu pracującego do wspólnoty państwowej. Umieszczenie już w pierwszym zdaniu k.p. kategorii ludu pracującego nie mogło przy tym pozostawać bez wpływu na ocenę znaczenia pracy w państwie realnego socjalizmu.

Przywołane zdanie wskazuje nie tylko na przywilej pracy. Obywatel Polskiej Rzeczypospolitej Ludowej nie tylko dysponował prawem do pracy, ale stanowiła ona obowiązek ciążący na każdym Polaku. W tym zakresie preambuła k.p. powtarzała wyrażony w art. 19 Konstytucji Polskiej Rzeczypospolitej Ludowej obowiązek. „Na gruncie Konstytucji z 1952 r. praca uzyskała szczególny status dobra, którego obowiązek zaspokojenia został nałożony na państwo. Powszechnie przyjmowano jednak, że konstytucyjny obowiązek pracy nie oznacza przymusu pracy, natomiast obywatelskie prawo do pracy nie ma charakteru podmiotowego"17. Przypomnienie w k.p. roli pracy w ustroju socjalistycznym wydaje się być naturalnym elementem polityki państwa i kształtowanych przez nie stosunków społeczno-gospodarczych. Nie bez znaczenia pozostało nie tylko kategoryzowanie pracy z perspektywy prawnej. Odwołanie się do sprawy honoru każdego obywatela nakazywało oceniać wypełnianie obowiązku pracy jako moralną powinność.

\section{Zasada jedności praw i obowiązków}

Przedmiotem szczególnego zainteresowania socjalistycznej nauki prawa pracy — w kontekście wcześniej sygnalizowanego konstytucyjnego obowiązku pracy

15 Zob. L. Florek, Ewolucja Kodeksu pracy, „Studia Iuridica Lublinensia” 24, 2015, nr 3, s. 31.

16 W. Zamkowski, Wstęp do nauk o państwie i prawie, Wrocław 1973, s. 47.

17 A. Dral, B. Bury, Zasada ochrony pracy w świetle Konstytucji RP, „Przegląd Prawa Konstytucyjnego" 2014, nr 3, s. 236 i przywołana tam literatura. 
— stał się fragment preambuły k.p. stanowiący jej ustęp $4^{18}$. Na podstawie jego treści sformułowano zasadę jedności pracowniczych praw i obowiązków. W kontekście przepisu art. 1 k.p. zasada ta „miała [...] stać się zasadą przewodnią prawa pracy, podkreślającą służebną rolę kodeksu w »umacnianiu socjalistycznych stosunków pracy «"19. Ponieważ omawiana zasada była związana z konstytucyjnym obowiązkiem pracy, stanowiła ona również podkreślenie znaczenia art. 12 k.p. w jego ówczesnym brzmieniu. Ustawodawca w ten sposób dał wyraz ideologicznym podstawom powinności pracownika: należytego wykonywania obowiązków, przestrzegania dyscypliny pracy, dążenia do uzyskiwania w pracy jak najlepszych wyników i przejawiania $\mathrm{w}$ tym celu odpowiedniej inicjatywy oraz dbania o dobro zakładu pracy $\mathrm{i}$ jego mienie. W efekcie powiązania wyrażonej w preambule zasady jedności praw i obowiązków z zawartymi w art. 12 k.p. podstawowymi obowiązkami pracownika doszło do sformułowania dyrektywy wykładni przepisów prawa pracy ${ }^{20}$.

Przyjęte rozwiązanie redakcyjne wyrażało obowiązującą w socjalistycznej nauce prawa ocenę relacji zachodzącej między prawami i obowiązkami obywatela. Formułowane opinie odnosiły się do „dialektycznej jedności i współzależności między prawami i obowiązkami obywatelskimi”"21. Jak słusznie współcześnie wyjaśnia Michał Seweryński, „,w doktrynie prawa pracy lansowano rozumienie zasady jedności praw i obowiązków nie jako wzajemność praw i obowiązków stron stosunku pracy (ta wzajemność w stosunku pracy także w tamtym czasie była zresztą oczywista i nie trzeba było dla niej tworzyć specjalnej zasady), lecz jako ideologiczne wzmocnienie pracowniczego obowiązku należytego wykonywania pracy, przestrzegania dyscypliny pracy oraz uzyskiwania najlepszych wyników pracy"22. Takie rozumienie zasady jedności praw i obowiązków pozostawało przy tym w spójności z oceną świadomości prawnej obywateli. Poprzez wyrażenie w preambule zasady jedności praw i obowiązków podkreślono konieczność „zajęcia się obowiązkami obywatelskimi i związaną z nimi odpowiedzialnością"23. W efekcie podkreślenia istoty obowiązków w statusie prawnym obywatela (tu w reżimie pracowniczym) nawiązano do zawartej w ustępie 2 preambuły kwestii dyscypliny pracy, ładu i porządku, do której przestrzegania miało wychowywać prawo pracy.

18 Ta część omawianego aktu stanowiła: „Kodeks kształtuje jednolity system praw i obowiązków pracowników. Zwiększając wymagania w zakresie obowiązków pracowniczych, od których należytego, sumiennego i twórczego spełniania zależy zasobność państwa i dobrobyt narodu, jednocześnie rozszerza uprawnienia pracownicze".

19 M. Seweryński, Refleksje na czterdziestolecie kodyfikacji prawa pracy, [w:] 40 lat Kodeksu pracy, red. Z. Góral, M.A. Mielczarek, Warszawa 2015, s. 23.

${ }^{20}$ Funkcja kodeksu w obrębie danej gałęzi prawa pozwala na sformułowanie wniosku o znaczeniu zawartej w preambule k.p. dyrektywy wykładni przepisów prawa pracy, a nie tylko przepisów samego kodeksu. Zob. J. Jończyk, Wprowadzenie, [w:] Kodeks pracy. Komentarz, red. J. Jończyk, Warszawa 1977, s. 5.

21 J. Jończyk, Jedność praw i obowiązków, „Nowe Drogi” 1975, nr 10, s. 69.

22 M. Seweryński, op. cit., s. 23 i przywołana tam literatura.

23 J. Jończyk, Jedność praw..., s. 75. 


\section{Zakład pracy jako podmiot zatrudniający}

Posłużenie się przez ustawodawcę w k.p. (w tym w jego preambule) sformułowaniem ,zakład pracy” było konsekwencją działań politycznych, ale również pociągało za sobą daleko idące skutki dla świadomości społecznej. Termin „zakład pracy” różni się od pojęcia „pracodawca”. Używano go dla określenia podmiotu stosunku pracy, ale też w sensie przedmiotowym jako ogół środków techniczno-organizacyjnych i majątkowych stanowiących pewną wyodrębnioną całość ${ }^{24}$. Zaraz po uchwaleniu k.p. zwrócono uwagę na trudności terminologiczne, wskazując, że „używana dawniej, krótka i powszechnie zrozumiała nazwa: »pracodawca« jest obciążona bagażem pojęć minionej epoki i przedstawia fałszywie rolę tego podmiotu (który bierze raczej, a ściślej przyjmuje świadczenie pracy, dając w zamian wynagrodzenie). W związku z tym stosuje się ją rzadko, raczej tylko w odniesieniu do stosunków pracy w gospodarce nieuspołecznionej" ${ }^{25}$. Przy uwzględnieniu znaczącego uspołecznienia środków produkcji pojęcie „,zakład pracy” definiowało jego charakter jako integralnej części państwowego aparatu gospodarczego ${ }^{26}$. Pojawiające się $\mathrm{w}$ dalszych przepisach prawa pracy sformułowanie „obowiązek przestrzegania reguł, mających zapewnić integrację poszczególnych zakładów pracy z całym państwowym aparatem gospodarczym i jednolitość funkcjonowania wszystkich jego części składowych"27 skutkowało pozbawieniem pełnej podmiotowości zakładu pracy jako podmiotu zatrudniającego. W efekcie realizacji między innymi założeń gospodarki centralnie planowanej państwo uzyskało status tak zwanego pracodawcy pośredniego obok zakładu pracy jako pracodawcy bezpośredniego, który wchodził w stosunki pracy z pracownikami.

Opisywane różnice terminologiczne służyły odcięciu się od poprzedniego ustroju społeczno-gospodarczego. Wprowadzenie pojęcia „zakład pracy” nie było przypadkowe - wiązało się z uspołecznieniem środków produkcji. Dotychczas wykorzystywany termin ,pracodawca” w swej formule niósł ze sobą zbyt dużą samodzielność podmiotu zatrudniającego, na którą w ustroju socjalistycznym nie było miejsca. W efekcie nowe pojęcie wpływało na świadomość prawną stron stosunku pracy oraz na kulturę prawną $\mathrm{w}$ obrębie prawa pracy. $Z$ powodu zwiększenia znaczenia państwa i jego organów w zakresie nadzoru nad świadczeniem pracy oraz przypisanie mu licznych kompetencji, które powinny należeć wyłącznie do pracodawcy, zakłady pracy działały w reżimie ograniczonej samodzielności. Taki stan rzeczy nie sprzyjał rozwojowi konkurencyjności gospodarki i innowacyjności. Wielość i różnorodność zakładów pracy funkcjonujących w gospodarce uspołecznionej nie pozwalały ich kierownikom podejmować indywidualnych

${ }^{24}$ Zob. W. Szubert, Zarys prawa pracy, Warszawa 1976, s. 85.

25 Ibidem, s. 84.

26 Zob. W. Szubert, Refleksje nad reforma prawa pracy, ,Ruch Prawniczy, Ekonomiczny i Socjologiczny" 1991, z. 1, s. 10.

27 Ibidem, s. 11. 
inicjatyw w interesie tych podmiotów. Podkreślono to już w ustępie 7 preambuły k.p. ${ }^{28} \mathrm{i}$ w sformułowanych tam obowiązkach kierownika socjalistycznego zakładu pracy. Brak pełnej podmiotowości podmiotu zatrudniającego nie służył również budowaniu wspólnoty zakładu pracy i rzeczywistej dbałości o jego los. Po roku 1989 dotychczasowa terminologia i pozycja zakładu pracy w stosunku pracy nie przystawała do nowych warunków gospodarczych.

\section{Podsumowanie}

Rola preambuły k.p. dalece wykraczała poza znaczenie prawne, a jej postanowienia niejednokrotnie wykazują charakter normatywny, na przykład chociażby poprzez określenie obowiązków kierownika socjalistycznego zakładu pracy. Liczne odniesienia w jej treści do wartości cenionych w socjalistycznym ustroju społeczno-gospodarczym uwypuklają przy tym polityczne znaczenie wstępu do k.p. Ideologiczne inklinacje niewątpliwie pełniły służebną rolę wobec oczekiwań klasy rządzącej. Wprowadzenie do ustawy treści o charakterze ideologicznym stanowi przykład prowadzenia przez władzę indoktrynacji we wszelkich sferach życia obywateli. Była ona realizowana nie tylko faktycznie, bowiem uwidaczniała się także w wymiarze normatywnym, czego dowodzi brzmienie i znaczenie preambuły k.p.

Pracę uczyniono nie tylko prawem jednostki, ale równocześnie jej obowiązkiem, a poprzez uznanie pracy za sprawę honoru przypisano jej także walor moralny. Tym zabiegiem ustawodawca wielowymiarowo wpływał na poczucie konieczności pracy w państwie ludu pracującego. W odpowiedzi na zgłaszane dysproporcje w określaniu i znajomości praw i obowiązków obywatelskich wyrażono w preambule zasadę jedności praw i obowiązków, służącą zdefiniowaniu kompleksowego statusu obywatela, na który składały się tak prawa, jak i obowiązki. W obszarze prawa pracy obowiązki ściśle wiązały się z dyscypliną pracy, czemu dano wyraz w treści analizowanego aktu. Stosowana siatka pojęciowa zaś odpowiadała etatystyczno-centralistycznemu modelowi prawa pracy ${ }^{29}$.

Preambuła k.p. nie przetrwała próby czasu. Na konieczność jej zmiany lub uchylenia wskazywano już w pierwszych latach istnienia III Rzeczypospolitej. Powodem tego rodzaju postulatów były elementy ideologiczne w jej treści, na które

${ }^{28}$ Ta część preambuły k.p. stanowiła, że: „Kierownik socjalistycznego zakładu pracy odpowiada za prawidłowe wykonywanie zadań zakładu wynikających z planu społeczno-gospodarczego rozwoju kraju [...] oraz zgodnie z zasadą jednoosobowego kierownictwa reprezentuje zakład pracy i zarządza tym zakładem pracy w imieniu państwa”.

${ }_{29}$ Zob. W. Szubert, Nowy model prawa pracy, ,Ruch Prawniczy, Ekonomiczny i Socjologiczny" 1988, z. 1, s. 4-5. 
uwagę zwracał poseł na Sejm Rzeczypospolitej Polskiej Kazimierz Pańtak ${ }^{30}$. Do nowego modelu gospodarczego nie przystawało ,skupienie w osobie państwa nie tylko imperium obejmującego wyłączność stanowienia norm, lecz również tytułu własności mienia uspołecznionego i wynikającego stąd zarządzania tym mieniem w sposób pozbawiający poszczególne przedsiębiorstwa samodzielności gospodarczej" 31 . W warunkach gospodarki wolnorynkowej oczekiwano usunięcia z preambuły k.p. treści wywodzących się z ideologii socjalistycznej, a także umożliwienia przedsiębiorstwom jako samodzielnym podmiotom zatrudniającym realizacji ich indywidualnych interesów. W związku z brakiem propozycji nowej treści preambuły k.p. postanowiono ją uchylić.

\section{Bibliografia}

Banaszak B., Konstytucja Rzeczypospolitej Polskiej. Komentarz, Warszawa 2012.

Banaszak B., Porównawcze prawo konstytucyjne wspótczesnych państw demokratycznych, Kraków 2004.

Choduń A., Sens ,,charakteru normatywnego”, ,,inGremio” 2016, nr 11, https://ingremio.org/2016/ 11/sens-charakteru-normatywnego/.

Complak K., [w:] Konstytucje Rzeczpospolitej oraz komentarz do Konstytucji RP z 1997 roku, red. J. Boć, Wrocław 1998.

Dral A., Bury B., Zasada ochrony pracy w świetle Konstytucji RP, „Przegląd Prawa Konstytucyjnego" 2014, nr 3.

Florek L., Ewolucja Kodeksu pracy, „Studia Iuridica Lublinensia” 24, 2015, nr 3.

Garlicki L., Preambuła, [w:] Konstytucja Rzeczypospolitej Polskiej. Komentarz, t. 5, red. L. Garlicki, Warszawa 2007.

Gwiżdż A., Wstęp do konstytucji —zagadnienia prawne, [w:] Charakter i struktura norm konstytucji, red. J. Trzciński, Warszawa 1997.

Jończyk J., Jedność praw i obowiązów, „Nowe Drogi” 1975, nr 10.

Jończyk J., Prawo pracy, Warszawa 1995.

Jończyk J., Wprowadzenie, [w:] Kodeks pracy. Komentarz, red. J. Jończyk, Warszawa 1977.

Muszalski W., Tworzenie i wydanie Kodeksu pracy - wspomnienie świadka, [w:] Prawo pracy. Między gospodarka a ochrona pracy. Księga jubileuszowa Profesora Ludwika Florka, red. M. LatosMiłkowska, Ł. Pisarczyk, Warszawa 2016.

Pedagogika, red. B. Milerski, B. Śliwerski, Warszawa, 2000.

Preambuła, [hasło w:] Wielki Stownik Języka Polskiego. O-Q, red. S. Dubisz, Warszawa 2018.

Seweryński M., Refleksje na czterdziestolecie kodyfikacji prawa pracy, [w:] 40 lat Kodeksu pracy, red. Z. Góral, M.A. Mielczarek, Warszawa 2015.

Sosnowski B., Geneza, rola i cechy preambuły w aktach prawnych, „Zeszyt Studencki Kół Naukowych Wydziału Prawa i Administracji UAM" 2016, nr 6.

Stafaniuk M.E., Preambuła aktu normatywnego $w$ doktrynie oraz $w$ procesie stanowienia i stosowania polskiego prawa w latach 1989-2007, Lublin 2009.

30 Zob. wypowiedź posła Kazimierza Pańtaka w trakcie 63. posiedzenia Sejmu Rzeczypospolitej Polskiej II kadencji z dnia 26 października 1995 roku, http://orka2.sejm.gov.pl/Debata2. nsf/4fb829a81a8d007ac125746d0030d0fb/7f5b5ba8338afe81c12574eb003ad36c?OpenDocument, dostęp: 30.10.2021.

31 W. Szubert, Nowy model..., s. 5. 
Szubert W., Nowy model prawa pracy, „Ruch Prawniczy, Ekonomiczny i Socjologiczny” 1988, z. 1. Szubert W., Refleksje nad reforma prawa pracy, „Ruch Prawniczy, Ekonomiczny i Socjologiczny” 1991, z. 1.

Szubert W., Zagadnienie kodyfikacji prawa pracy, „Państwo i Prawo” 1962, z. 8-9.

Szubert W., Zarys prawa pracy, Warszawa 1976.

Trzciński J., Charakter i struktura norm konstytucyjnych, [w:] Projekt Konstytucji RP w świetle badań nauki prawa konstytucyjnego, red. K. Działocha, A. Pułł, Gdańsk 1998.

Wawrzyniak J., Zarys polskiego ustroju konstytucyjnego, Bydgoszcz 1999.

Wyrok Naczelnego Sądu Administracyjnego z dnia 6 sierpnia 1984 roku, sygn. akt II SA 735/84.

Zamkowski W., Wstę do nauk o państwie i prawie, Wrocław 1973. 